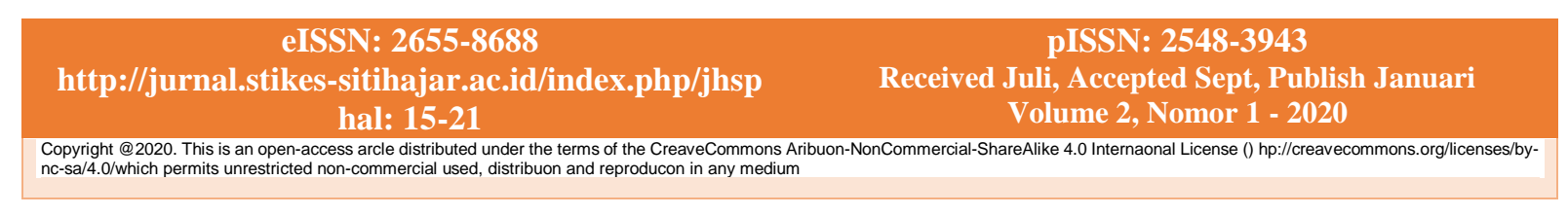

\title{
Potensi Terapi Tertawa Sebagai Terapi Hipertensi
}

\author{
Fakhira Arminda ${ }^{1 *}$ \\ Fakultas Kedokteran Universitas Lampung \\ Email: ${ }^{1}$ armindafakhira@gmail.com
}

\begin{abstract}
ABSTRAK
Terapi tertawa adalah suatu terapi untuk mencapai kegembiraan, kesenangan, kebahagiaan, didalam hati yang dikeluarkan melalui mulut dalam bentuk suara tawa, senyuman yang menghiasi wajah, suara hati yang lepas dan bergembira, peredaran darah yang lancar sehingga bisa mencegah penyakit, memelihara kesehatan, serta menghilangkan stress. Walaupun sudah ditemukan sejak lama, dalam bidang medis sendiri penggunaan terapi tertawa sebagai terapi suatu penyakit sangat jarang dijumpai. Seperti dikatakan sebelumnya bahwa terapi tertawa dapat menghilangkan stress, dimana stress sendiri sangat berhubungan dengan hipertensi. Hipertensi adalah kondisi pisikal yang berhubungan dengan stres negatif atau distress. Stress secara psikologikal, emosi, dan pisikal merupakan hasil respon dari sebuah masalah yang mengancam keberadaan seseorang. Karena stress berhubungan dengan persepsi, maka dalam pelengkap penatalaksanaan klinis diperlukan penatalaksanaan non-farmakologi terkhususnya pasien hipertensi dengan mencoba terapi tertawa.
\end{abstract}

Kata kunci : hipertensi, stres, terapi tertawa

\section{ABSTRACT}

Laughter therapy is a therapy to achieve joy, pleasure, happiness, in the heart that is issued through the mouth in the form of laughter, smiles that decorate the face, loose and happy conscience, blood circulation that can be adapted to disease, health care, can also be help emphasize. It has been found a long time ago, in the medical field itself the use of laughter therapy as a therapy for disease is very rare. As explained earlier, therapy can relieve stress, whereas stress itself is highly related to hypertension. Hypertension is a problem related to negative stress or pressure. Psychologically, logically, and psychologically emphasize the results of responses to problems involving a person. Because stress is related to perception, complementing clinical management requires the management of non-pharmacology, especially hypertensive patients by trying laughter therapy.

Keywords: hypertension; emphasize; laugh therapy 


\section{Pendahuluan}

Terapi tertawa merupakan salah satu terapi untuk menggapai kesenangan didalam hati yang diungkapkan melalui mulut dalam bentuk suara tawa, senyuman yang menghias wajah, suara hati yang lepas dan bergembira, dapat menyebabkan peredaran darah yang lancar sehingga memiliki manfaat mencegah penyakit, serta memelihara kesehatan, dan juga menghilangkan stres (Setyoadi, 2011).

Terapi tertawa adalah ekspresi jiwa atau emosional yang diperlihatkan melalui raut wajah dan bunyi-bunyian tertentu. Terapi tawa termasuk dalam strategi koping yang berfokus pada emosi yaitu emotional focused coping, karena fokus utama terapi tawa ini adalah untuk memperbaiki emosi negatif menjadi emosi positif. Terapi tawa atau humor adalah cara alami untuk menghadapi sakit mental dan perasaan tertekan. Meskipun cara ini tidak dijamin berhasil untuk semua kasus, dan keberhasilannya tergantung pada seberapa lama gangguan itu dialami, akan tetapi setidaknya tersenyum akan membuat penderita lebih riang dan sementara terbebas dari masalah (Prasetyo \& Nurtjahjanti, 2012).

Hipertensi adalah contoh dari salah satu penyakit sistem kardiovaskuler yang semakin banyak ditemui di masyarakat. Riset kesehatan dasar Indonesia tahun 2007-2018 menyebutaan bahwa jumlah penderita hipertensi di seluruh Indonesia berdasarkan hasil pengukuran pada penduduk berusia $\geq 18$ tahun mencapai $34,1 \%$. Pada riskesdas tersebut disebutkan pula hanya terdapat $8,8 \%$ penduduk umur $\geq 18$ tahun yang terdata berdasarkan diagnosis atau minum obat antihipertensi, dan 32,3\% dari data tersebut tidak meminum obat secara rutin karena berbagai alasan yang ada (Riskesdas, 2018). Sedangkan apabila penyakit hipertensi tidak dipantau dan tidak diobati secara rutin, maka dapat menyebabkan berbagai komplikasi yang berujung kematian. Komplikasi pada hipertensi yaitu gagal jantung, iskemia dan infark miokard, stroke iskemik, aneurisma dan diseksi, stroke hemorragik, nefrosklerosis dan gagal ginjal, dan retinopati(Yogiantoro, 2014)

Diketahui bahwa, komplikasi pada hipertensi menyebabkan 9,4 juta kematian pada sekitar 17 juta kematian akibat penyakit kardiovaskular di dunia. Hipertensi bertanggung jawab terhadap $45 \%$ kematian akibat penyakit jantung iskemik, dan 51\% kematian akibat stroke. Hipertensi membunuh hampir 1,5 juta orang setiap tahun di Asia Tenggara, sehingga menjadi salah satu faktor risiko tunggal yang paling penting untuk penyakit tidak menular seperti serangan jantung dan stroke (WHO, 2013).

Berdasarkan penyebabnya hipertensi dibagi menjadi dua golongan, yaitu hipertensi primer dan hipertensi sekunder. Hipertensi primer atau hipertensi esensial merupakan hipertensi yang penyebabnya tidak diketahui, sering dikenal sebagai hipertensi idopatik. Hipertensi ini paling sering terjadi, sekitar 95\% kasus hipertensi. Beberapa faktor yang mempengaruhi hipertensi ini diantaranya adalah faktor genetik, lingkungan, hiperaktivitas susunan saraf, serta faktor-faktor yang meningkatkan risiko seperti obesitas, alkohol, merokok. Hipertensi primer tidak dapat disembuhkan dan cenderung berkembang secara bertahap selama bertahun-tahun, meski begitu hipertensi primer dapat dikendalikan dengan terapi yang tepat (termasuk modifikasi gaya hidup dan obat) (Bell \& Twiggs, et al, 2018).

Hipertensi sekunder atau hipertensi renal, terdapat sekitar 5\% kasus hipertensi jenis ini. Hipertensi jenis ini disebabkan oleh kondisi medis ataupun penggunaan obat tertentu. Dengan demikian, untuk terapi yang dibutuhkan adalah mengontrol kondisi kesehatan yang mendasari atau menghentikan penggunaan obat tersebut. Penyebab paling umum dari hipertensi sekunder dikaitkan dengan adanya gangguan ginjal seperti penyakit ginjal kronis atau penyakit renovaskular. Hipertensi sekunder cenderung muncul mendadak dan sering menyebabkan tekanan darah yang lebih tinggi dari bentuk hipertensi primer (Bell \& Twiggs, et al, 2018).

Stres sering dikaitkan dimasyarakat dengan tekanan darah tinggi. Penelitian oleh Kurniawan \& Sulaiman (2019) menunjukkan bahwa terdapat hubungan yang bermakna secara statisitik antara stres dengan tingkat hipertensi. Perbuatan yang kurang terkontrol secara sehat 
dapat saja muncul dikarenakan stres yang berkaitan dengan beban rohani seseorang yang melebihi kemampuan rohani itu sendiri. Stres muncul dalam berbagai tingkatan terhantung pada keadaan rasa sakit dan umur individu yang bersangkutan (Kurniawan \& Sulaiman, 2019). Stres dapat bersifat positif dan negatif. Stres positif disebut juga eustress, eustress, yang terjadi apabila taraf stres yang dialami mendorong atau memotivasi individu untuk meningkatkan usaha pencapaian tujuan. Sebaliknya, stres yang negatif disebut juga distress, mengandung emosi negatif yang sangaat kuat sehingga tidak hanya mengancam kesehatan, kognitif, emosi, serta perilaku seseorang (Pinel, 2009) (Schafer, 1998).

Sumber stres disebut stressor yang dapat berupa keadaan tubuh, keadaan lingkungan, pemicu dari luar atau sebuah kejadian yang dipersepsi mengancam oleh individu. Stresor mempengaruhi sistem saraf melalui sirkuit-sirkuit neural dan menstimulasi pelepasan ACTH dari ptuituari anterior sehinggga memicu pelepasan glukokotikoid dari korteks adrenal. Dalam keadaan ini glukokortikoid banyak menghasilkan respon stres. Selain itu stressor juga mengaktifkan sistem saraf simpatetik, sehingga meningkatkan jumlah epinephrine dan norephinephrine yang dilepaskan dari medulla adrenal. Pada saat individu mengalami stres yang lama, tubuh yang mengalami stres terus menerus akan mengalami kelelahan dalam mempreduksi hormon adrenalin dan epinephrine. Hal ini dapat memperburuk kondisi tubuh sehingga dapat menjadi fatigue dan penurunan sistem imunitas. Kelelahan dalam memproduksi adrenalin dapat disebabkan olehketegangan emosional, seperti frustasi. Oleh karena itu, penting bagi seseorang untuk mengembalikan kondisi ke keadaan rileks agar terjadi penurunan kerja sistem saraf tersebut (Schafer, 1998).

Terapi tertawa adalah salah satu cara untuk mencapai kondisi rileks. Terapi tawa merupakan salah satu intervensi psikologi yang sederhana dan ekonomis, prinsipnya hanya dibutuhkan individu dapat tertawa yang akan merelaksasikan otot-otot yang tegang. Tertawa juga melebarkan pembuluh darah sehingga dapat memperlancar aliran darah ke seluruh tubuh. (Anwar, 2015).

Terapi tawa juga dapat meningkatkan kesehatan fisik dan psikologis. Secara medis terapi tawa dapat mengurangi stress dengan menurunnya hormon kortisol dan epinephrine. Tertawa juga dapat melepaskan hormon endorphin yang dapat meredakan rasa sakit pada fisik dan meningkatkan jumlah sel-sel yang memproduksi antibodi dan meningkatkan efektifitas sel yang mengarah ke system kekebalan tubuh yang lebih kuat (Satish, 2012; Gelkopf, 2011).

Terapi tertawa adalah salah satu cara untuk mencapai kondisi rileks. tertawa adalah respon fisiologis untuk humor. Tertawa terdiri dari dua komponen yaitu satu set isyarat dan produksi bunyi ketika tertawa, otak memaksa tubuh untuk melakukan kedua aktivitas tersebut secara serempak, sedangkan dalam ilmu fisiologis tertawa adalah ekspresi wajah yang terjadi akibat dari timbulnya suatu gerakan dibibir, di ke dua ujung bibir, atau di sekitar mata Terapi tertawa merupakan tertawa yang dimulai dengan tahap demi tahap sehingga efek yang dirasakan bagi yang tertawa benar-benar bermanfaat. Selain pemberian terapi tawa diperlukan latihan pernafasan dalam dan panjang antara latihan teknik tawa stimulus. Hal ini untuk mencegah kelelahan karena tawa seperti latihan aerobic yang melibatkan kontraksi abdominal dan pernafasan yang berat. (Tria, 2008)

\section{Metode}

Literature review ini ditulis engan metode studi pustaka dengan mengambil data dan referensi dari berbagai buku dan jurnal ilmiah yag valid. Jurnal tersebut dicari melalui data dari PUBMED (NCBI), ResearchGate, Google scholar, dan Pharmaceutical Journal.Tanpa batasan waktu dan didapatkan beberapa artikel yang memenuhi kriteria kemudian disusun dalam literature review ini. 


\section{Hasil dan Pembahasan}

Pada penelitian yang dilakukan oleh Sheni (2013) Untuk mengetahui dampak terapi tawa terhadap tingkat stres subjek penelitian, dilakukan pengukuran tingkat stres pada sebelum, sesudah, dan periode tindak lanjut. Pada pengukuran pre-test, rerata skor skala stres subjek penelitian baik dari kelompok eksperimen maupun kelompok kontrol mengindikasikan adanya kategori stres tingkat sedang $(80<\mathrm{X}<120)$ Pada pengukuran post-test, skor kelompok eksperimen mengalami penurunan stres pada kategori rendah. Sebaliknya kelompok kontrol menunjukan sedikit peningkatan rerata skor stres dari 97,17 menjadi 97,83.

Sebelum diberi intervensi, rerata tekanan darah sistolik dan diastolik dari kelompok subjek eksperimen 142/76 mmHg pada saat post-test terjadi penurunan rerata tekanan darah menjadi 118/71 mmHg (Desinta, 2013).

Tabel 1 Rangkuman Uji Mann-whitney Skala Stres antara kelompok eksperimen dan kontrol

\begin{tabular}{ll}
\hline Sumber Data & $\mathrm{Z}$ \\
\hline Selisih skor pre post-test & $-2,287^{*}$ \\
Selisih skor post follow up & $-0,161$ \\
Selisih skor pre follow up & $-2,33^{*}$ \\
\hline
\end{tabular}

Keterangan: *signifikansi $\mathrm{p} \leq 0,01 *$ signifikansi $\mathrm{p} \leq 0,05$

Teknik statistik nonparametrik terhadap selisih post-test dan pre-test memperlihatkan bahwa terapi tawa efektif menurunkan stres pada penderita hipertensi. Hal ini diperlihatkan oleh adanya penurunan yang signifikan dari skor skala simtom stres kelompok eksperimen dibandingkan dengan kelompok kontrol.

Pada penelitian ini penetelian dilakukan di puskesmas, dua kali seminggu sesuai kesepakatan hari dan waktu dengan peserta dengan alur kegiatan yaitu dimulai dengan sesi pengenalan terapi tertawa, dilanjutkan pengenalan dan latihan teknik pernafasan dalam (diafragma), teknik peregangan, dan latihan gerakan ritmis diafragma dengan mengucapkan "ho ho ha ha ha". Pernafasan ini dapat menimbulkan perasaan lebih rileks dan lebih sehat. Selain itu, secara instan dapat mengurangi stres dengan mengeluarkan nafas yang panjang secara perlahan (Greenberg, 2008). Penggunaan pola "ha ha ha" merupakan pola respiratori yang sudah terasosiasi dengan tawa (pengukuran aktifitas tawa dengan menggunakan laryngeal electromyography, abdominal muscle (EMG, dan electrocardiogram). Meskipun akan sangat bervariasi dengan durasi yang berbeda, namun pola tertawa ini berbeda dengan pada saat seseorang batuk, ataupun bersin. Hal ini juga yang membuat tertawa membuat seseorang lebih sehat (Kimata, et al., 2009). Selanjutnya kegiatan dilanjutkan dengan latihan teknik tawa stimulus. Terapi tawa ini akan dilakukan dalam enam pertemuan dengan durasi waktu 30 menit.

Pada penelitian ini pula di gunakan tiga macam teknik tawa stimulus yaitu tawa yoga, tawa bermain, dan tawa berdasarkan nilai-nilai tertentu, dilatihkan secara bergantian hingga subjek penelitian dapat melakukannya sendiri. Teknik tawa yoga dikembangkan dari postur yoga untuk kesehatan tubuh. Teknik tawa bermain bertujuan agar orang suka bermain dan mengurangi rasa malu dan takut. Sikap bermain-main juga membantu tawa stimulus menjadi tawa spontan. Teknik tawa berdasarkan nilai yaitu teknik tawa yang dirancang sehingga melekatkan ilai-nilai tertentu yang dibuat ketika sedang tertawa. Hal ini untuk membantu mengembangkan dilai positif sehari-hari (Nelson, 2008)

Dalam pelaksanaannya, terapi tawa ini menggunakan pendekatan kelompok. Hal ini dilakukan atas dasar aspek komunikasi yang terkandung pada saat tertawa. Di dalam kelompok, dapat terjadi kontak mata, sehingga cara ini untuk menambah efektivitas dan menghasilkan tawa secara alamiah. Kontak mata berfungsi sebagai stimulus karena tertawa juga merupakan 
suatu bentuk interaksi sosial dan dapat menular.Hasil analisis data dari penelitian ini menunjukan adanya perbedaan yang signifikan pada tekanan darah sistolik antara kelompok eksperimen dengan kelompok kontrol setelah mengikuti terapi tawa. Sebaliknya, uji yang sama terhadap selisih tekanan darah diastolik menunjukan tidak adanya perbedaan yang signifikan antara kedua kelompok. Berdasarkan hasil tersebut dapat disimpulkan bahwa terapi tawa dapat menurunkan tingkat stres dan tekanan darah sistolik pada penderita hipertensi.

Hal lain yang juga menjadi perhatian dalam penelitian ini adalah kondisi tekanan darah dapat dipengaruhi oleh banyak faktor yaitu pengobatan yang sudah dijalani oleh subjek, olahraga, pengurangan konsumsi garam, pengaturan pola makan dan berat badan. Salah satu yang menjadi kelemahan pada penelitian ini yaitu sedikitnya jumlah subjek penelitian.

Terdapat penelitian lain yang membahas pengaruh terapi terapi tertawa terhadap penurunan tekanan darah yang dilakukan di Puskesmas Olak Kemang kota Jambi oleh Nurhusna, Yosi Oktarina, dan Andika Sulistiawan (2018) (Nurhusna, Oktarina, \& Sulistiawan, 2018). Dimana desain penelitian yang digunakan adalah quasi experimental design dengan "Pre-test and post-test two group design" dengan dua kelompok responden yaitu kelompok intervensi yang mendapat perlakuan terapi tertawa, kelompok kontrol pada masing-masing kelompok akan dilakukan pengukuran pre intervensi satu kali dan post intervensi setiap minggu.

Tabel 2. Rerata Tekanan Darah Responden pada kelompok Intervensi Dan Kontrol Sebelum Dilakukan Terapi Tertawa $(\mathbf{n}=28)$

\begin{tabular}{lllll}
\hline $\begin{array}{l}\text { Kelompok } \\
\text { Penelitian }\end{array}$ & Variabel & Mean & $\begin{array}{l}\text { Standar } \\
\text { Deviasi }\end{array}$ & Nilai Min - Max \\
\hline Intervensi & Sistolik & 151,43 & 11,637 & $140-170$ \\
& Diastolik & 95 & 5,189 & $90-100$ \\
\multirow{3}{*}{ Kontrol } & Sistolik & 149,29 & 9,972 & $140-170$ \\
& Diastolik & 92,14 & 4,258 & $90-100$ \\
\hline
\end{tabular}

Berdasarkan tabel 2. Diketahui bahwa rata-rata tekanan darah sistolik pada kelompok intervensi sebelum dilakukan intervensi adalah $151,43 \mathrm{mmHg}$ dan rata-rata tekanan darah sistolik pada kelompok kontrol sebelum dilakukan intervensi adalah 149,29 mmHg. Sedangkan nilai rata-rata tekanan darah diastolik pada kelompok intervensi dan kontrol adalah 93, 57 mmHg dan 92,14 mmHg.

Tabel 3. Rerata Tekanan Darah Responden pada kelompok Intervensi Dan Kontrol Sesudah Dilakukan Terapi Tertawa $(n=28)$

\begin{tabular}{lllll}
\hline $\begin{array}{l}\text { Kelompok } \\
\text { Penelitian }\end{array}$ & Variabel & Mean & $\begin{array}{l}\text { Standar } \\
\text { Deviasi }\end{array}$ & Nilai Min - Max \\
\hline Intervensi & Sistolik & 137,14 & 12,044 & $120-160$ \\
& Diastolik & 85 & 5,189 & $120-160$ \\
\multirow{2}{*}{ Kontrol } & Sistolik & 149,29 & 9,972 & $140-170$ \\
& Diastolik & 92,14 & 4,258 & $90-100$ \\
\hline
\end{tabular}

Berdasarkan tabel 3. Diketahui bahwa rata-rata tekanan darah sistolik pada kelompok intervensi setelah dilakukan intervensi adalah 137,14 mmHg dengan nilai minimum 120 dan maximum 160. Dan rata-rata tekanan darah sistolik pada kelompok kontrol setelah dilakukan intervensi adalah 149,29 mmHg dengan nilai minimum 140 dan maksimum 170. Sedangkan 
dilai rata-rata ekanan darah diastolik pada kelompok intervensi dan kontrol setelah dilakukan intervensi adalah $85 \mathrm{mHg}$ dan $92,14 \mathrm{mmHg}$

Tabel 4. Perbedaan Rata-rata tekanan darah sebelum dan sesudah dilakukan terapi tertawa pada kelompok kontrol di kelurahan Ulu Gedong Wilayah Kerja Puskesmas Olak Kemang $(\mathbf{n}=\mathbf{1 4})$

\begin{tabular}{llllll}
\hline $\begin{array}{l}\text { Tekanan } \\
\text { Darah }\end{array}$ & Variabel & Mean & Selisih & $\begin{array}{l}\text { Standar } \\
\text { Deviasi }\end{array}$ & $\begin{array}{l}\text { Nilai P- } \\
\text { Value }\end{array}$ \\
\hline Sistolik & Pre test & 149,29 & 0 & 9,972 & \\
& Post test & 149,29 & & 9,100 & 0,157 \\
Diastolik & Pre test & 92,14 & 0 & 4,258 & \\
& Post test & 92,14 & & 5,789 & 1,000 \\
\hline
\end{tabular}

Pada tabel 5. Diketahui bahwa tidak ada perbedaan mean sebelum dan sesudah pada tekanan darah diastolik, yatitu selisih mean sebesar 0. Nilai mean pre dan post adalah 149,29 adapun $\mathrm{p}$ value tekanan darah sistolik 0,157 dan $\mathrm{p}$ value tekanan darah diastolik 1,000, sehingga dapat disimpulkan tidak ada pengaruh terapi tertawa terhadap tekanan darah sistolik pada kelompok kontrol lansia.

Tabel 5. Perbedaan Rata-rata tekanan darah sebelum dan sesudah dilakukan terapi tertawa pada kelompok kontrol di kelurahan Ulu Gedong Wilayah Kerja Puskesmas Olak Kemang $(n=14)$

\begin{tabular}{llll}
\hline Tekanan Darah & Variabel & Nilai P-Value Uji Mann-whitney & $\begin{array}{l}\text { Mean } \\
\text { Rank }\end{array}$ \\
\hline Sistolik & Intervensi & 0,003 & 9,57 \\
& Kontrol & & 19,43 \\
Diastolik & Intervensi & 0,004 & 10,25 \\
& Kontrol & & 18,75 \\
\hline
\end{tabular}

Setelah dilakukan uji statistik dengan uji Man-whitney diperoleh p-valuer tekanan darah sistolik 0,003. Sehingga dapat disimpulkan ada pengaruh terapi tertawa terhadap tekanan darah sistolik pada lansia dengan hipertensi. Dan P value tekanan darah diastolik adalah 0,004. Maka dapat disimpulkan bahwa ada pengaruh pengaruh terapi tertawa terhadap tekanan darah diastolik pada lansia dengan hipertensi.

Berdasarkan hasil penelitian, setelah dilakukan intervensi terjadi penurunan tekanan darah pada kelompok intervensi yaitu 137,14/85 mmHg. Berdasarkan klasifikasi hipertensi, tekanan darah tersebut diklasifikasikan sebagai tahap pra hipertensi. Pra hipertensi adalah tekanan darah sistolik 130-139 $\mathrm{mmHg}$ dan tekanan darah diastolik 85-89 mmHg. Adanya penurunan tekanan darah pada kelompok intervensi yaitu dikarenakan responden mendapatkan terapi tertawa. Penjelasan pada penelitian ini kurang lebih sama dengan penelitian sebelumnya dimana dikatakan tertawa merupakan paduan dari peningkatan sitem saraf simpatik dan juga penurunan kerja sistem saraf simpatik. Peningkatannya berfungsi untuk memberikan tenaga bagi gerakan pada tubuh, namun hal ini kemnudian juga diikuti oleh penurunan sistem saraf simpatik yang salah satunya disebabkan oleh adanya perubahan kondisi otot yang menjadi lebih rileks, dan pengurangan terhadap pemecahan nitric oxide yang membawa pada pelebaran pembuluhdarah, sehingga rata-rata tertawa menyebabkan aliran darah sebesar $20 \%$, sementara stres menyebabkan penurunan aliran darah sekitar 30\%. Hal tersebut menunjukkan bahwa terapi tertawa dapat menurunkan tekanan darah khususnya pada penderita hipertensi. 


\section{Kesimpulan}

Dari beberapa penelitian yang telah dilakukan didapatkan hasil yang selaras yaitu terjadi penurunan tekanan darah. Penelitian-penelitian tersebut memberikan rekomendasi terhadap pemanfaatan terapi tawa untuk membantu penderita hipertensi dalam menurunkan tekanan darahnya. Tertawa menyebabkan penurunan sistem saraf simpatetik yang salah satunya disebabkan oleh adanya perubahan kondisi otot yang menjadi lebih rileks dan pengurangan pemecahan terhadap nitric oxide yang membawa pada pelebaran pembuluh darah sehingga tekanan darah menurun. Terlepas dari keberhasilan terapi tawa dalam menurunkan tingkat stres dan tekanan darah subjek dengan hipertens, beberapa penelitian diatas masih membutuhkan pengujian lebih lanjut dengan subjek yang lebih banyak dan lebih sejenis dengan mengurangi bias pada keberagaman subjek (Nurhusna, Oktarina, \& Sulistiawan, 2018).

\section{Referensi}

Anwar, Z. (2015). Terapi tawa untuk healing dan recovery trauma pasca bencana. Procedia Studi Kasus \& Intervensi Psikologi, 3, 50-54. https://doi.org/10.1017/CBO9781107415324.004

Bell, K., Twiggs, J., \& Olin, B. (2018). Hypertension: The Silent Killer: Updated JNC-8 Guideline Recommendations. United States: Alabama Pharmacy Association.

Desinta S. 2013. Terapi tawa untuk menurunkan stres. Jurnal Psikologi Universitas Gadjah Mada, 15-27.

Gelkopf, M. (2011). The use of humor in serious mental illness: A review. Evidence-Based Complementary and Alternative Medicine.

Greenberg J. 2008. Comprehensive stress management 10th ed. New York: McGraw-hill.

Kimata H, Morita A, Furuhata S, Itakura H, Ikenobu K, \& Kimura Y. 2009. Assessment of laughter by diaphragm electromyogram. European Journal of Clinical Investigation, 78-79.

Kurniawan, I., \& Sulaiman. (2019). Hubungan olahraga, stress dan pola makan dengan tingkat hipertensi di posyandu lansia di Kelurahan Sudirejo I Kecamatan Medan Kota. Journal of Health Science and Physiotherapy, 1(1), 10-17.

Mustacchi. 1990. Stress and hyper-tension. The Western Journal Of Medicine August, 153(2)

Nelson J. 2008. Laugh and the world laughs with you: An attachment perspective on the meaning of laughter in psychotherapy. Clinical Social Work Journal, 41-49.

Nurhusna, Oktarina Y, \& Sulistiawan A. 2018. Pengaruh terapi tertawa terhadap penurunan tekanan darah penderita hipertensi di Puskesmas Olak Kemang Kota Jambi. Jurnal Ilmiah Ilmu Terapan Universitas Jambi 1(1), 75-81.

Pinel. 2009. Biopsikologi 7ed. Yogyakarta: Pustaka Pelajar.

Prasetyo, A. R., \& Nurtjahjanti, H. (2012). Pengaruh Penerapan Terapi Tawa Terhadap Penurunan Tingkat Stres Kerja Pada Pegawai Kereta Api. Jurnal Psikologi Undip, 11(1), 59-72. https://doi.org/10.14710/jpu.11.1.14

Riskesdas. (2018). Hasil Utama Riskesdas di Indonesia 2018. Hasil Utama Riskesdas Tentang Prevalensi Diabetes Melitus Di Indonesia 2018, 8. https://doi.org/1 Desember 2013

Satish, D. (2012). Laughter therapy. Journal of Pharmaceutival and Scientific Innovation, 1(3), 23-24. https://doi.org/10.7748/ns.21.16.28.s46

Schafer W. 1998. Stress management for wellness. New York: Wadsworth Group.

Setyoadi K. 2011. Terapi modalitas keperawatan pada klien psikogeriatri. Jakarta: Salemba Medika.

Tria. 2008. Seni membaca senyum. Jakarta Timur: Percetakan Hi-Fest.

WHO. 2013. A global brief on Hypertension World Health Day 2013 [Online Journal] [diunduh 10 Maret 2017]. Tersedia dari: https://www.who.int.

Yogiantoro, M. (2014). Buku Ajar PAPDI.pdf. In Buku Ajar Ilmu Penyakit Dalam (6th ed., pp. 2313-2337). Jakarta: InternaPublishing. 